\title{
Las relaciones prehispánicas entre el Perú y la Argentina*
}

Max Uhle

\section{NOTA INTRODUCTORIA}

Al ser el tema del dossier de este nuevo número de Antropología Cuadernos de InVEstigación "Relaciones interregionales en los Andes Septentrionales", hemos Considerado Pertinente presentar en la sección Testimonios este texto de Max Uhle, titulado "Las relaciones prehistóricas entre el Perú y la Argentina". El documento, publicado en 1912 en Buenos Aires, es un extracto de las Actas del XVII Congreso Internacional de Americanistas, y es difícil conseguirlo en el Ecuador, al igual QUe muchos DE LOS TEXTOS DE ESTE AUTOR.

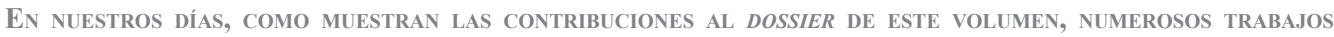
DE CAMPO HAN SACAdO A LA LUZ GRANDES CANTIDAdES DE ElEMENTOS CONTEXTUALIZAdOS QUE NOS FACILITAN LA

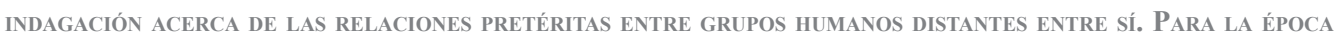
de Uhle, previa al descubrimiento del Carbono 14 Como método de datación absoluta, y Con muchos MENOS ELEMENTOS ARQUeOLógicos CONTEXTUALIZAdos PROVENIENTES DE EXCAVACIONES CONTROLADAS, DEBía ECHARSE MANO A OTRO TIPO DE REFLEXIONES E INDAGACIONES, COMO LA COMPARACIÓN DE ELEMENTOS ESTILÍSTICOS E ICONOGRÁFICOS.

Más allá de que hoy Sepamos que, en algunos de los Casos, Uhle SE equivocó con SuS hiPótesis de RELACIONES O INFLUENCIAS, FORMULADAS EN EL ESTILO DIFUSIONISTA QUE CARACTERIZA SU ÉPOCA, RESULTA DIGNA DE MENCIÓN SU PREOCUPACIÓN POR VER MÁS ALLÁ DE HALLAZGOS AISLADOS Y BUSCAR UNA VISIÓN SUPRARREGIONAL

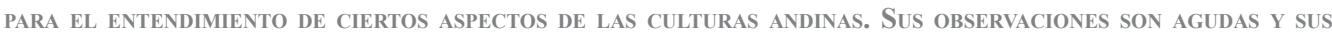
APRECIACIONES NO SON ANTOJADIZAS, Y VISTAS EN PERSPECTIVA, A MÁS DE UN SIGLO DE HABER SIDO PUBLICADAS, ES SIN DUDA DE INTERÉS REVISARLAS Y APRECIAR SUS ESFUERZOS INVESTIGATIVOS.

María FERNANDA UGALDE

* Extracto de las Actas del XVII ${ }^{\circ}$ Congreso Internacional de Americanistas, pag. 509 y siguientes. 
MAX UHLE

(LIMA)

\section{LAS RELACLONES PRBHISTÓRICAS \\ ENTRE}

EL PERU Y LA ARGENTINA

Extracto de las Actas deL xviro Congreso Internacronal DE Ambrioanista8, pág. 509 y siguientes

BUENOS AIRES

IMPRENTA DE CONI HERMANOB

684, PFRT, 684

1912 
$\mathrm{N}$ o hay capítulo de cuestiones arqueológicas en que se necesita tanto de una precisión de términos cronológicos como en el de las relaciones entre diferentes países ó civilizaciones que con ellos se identifican. Á esta falta se debe que el problema de las relaciones entre las civilizaciones antiguas del Perú y la Argentina, tan antiguo como la idea de ellas mismas, no se haya podido resolver hasta el día; aún no se ha dado ningún paso adelante desde los tiempos de Bárcena, en el siglo XVI. SI se tratase hoy de la civilización de la India oriental, en su relación con la del occidente, no se le ocurriría á nadie pretender que toda aquella civilización haya derivado de la europea; tampoco que la civilización griega ó la inglesa ó la del Islam formaron sus únicas fuentes. Lo que no se hace respecto á países cuyas relaciones pasadas conocemos, tampoco se debe hacer respecto á relaciones de países americanos cuya historia lejana estudiamos. Sabríamos mucho más acerca de las relaciones de las civilizaciones centro-americanas con los moundbuilders, si nos hubiésemos acostumbrado á contemplar las primeras, de apariencia uniforme para el observador moderno, que las ve bajo el prisma de su diferente radiación por los siglos y, de la misma manera, las relaciones que evidentemente hubo, en cierto tiempo, entre las civilizaciones centro americanas con Colombia, no se determinarán de una manera más clara hasta que no hayamos separado los siglos de la civilización de los Mayas de las otras centro americanas y mexicanas, igual ó más importantes en la historia que aquélla.

Los misioneros del siglo XVI en la Argentina, no conocían otra civilización extraña de efectos tan antojadizos sobre la indígena como la de los incas, y de ahí vino la idea de que la civilización cuya destrucción presenciaban, había sido introducida por aquéllos. Como ideas extremas siempre provocan las opuestas, Lozano negó rotundamente el peso de todos los argumentos anteriores, vindicando para la civilización calchaquí que observaba, un origen enteramente propio. El mismo juego, que es más un juego de palabras que de argumentos, se observa en la arqueología moderna, bajo otros aspectos tan adelantada. Una de las últimas obras, la más completa y la más compendiada escrita hasta ahora sobre las civilizaciones del noroeste argentino, se decide en favor del origen peruano incaico de las civilizaciones calchaquí, por las siguientes razones: igualdad de las técnicas y del as formas en general, en los objetos de barro, piedra y metal; semejanza general en la forma de los entierros y edificios de piedra; importación de conchas marinas; uso de la lengua quechua; hallazgos de aríbalos incaicos, cabecitas de gato de barro de carácter peruano; uno de hornos de aíre para la fundación, de la liga de estaño y cobre, y de la llama para obtener lana para tejidos. El Autor que escribió esto, no ha visto que la primera parte de las pruebas aducidas se refiere á caracteres demasiado generales que permiten demostrar la relación entre cualesquiera de las antiguas civilizaciones americanas, y que la segunda se refiere á la civilización incaica, la que, según descubrimientos modernos, es de origen demasiado nuevo para explicar el origen de toda la civilización del noroeste argentino.

No es sólo eso: las relaciones de los incas con la Argentina son más nuevas todavía, remontándose, más ó menos, á un siglo ó siglo y medio antes de la entrada de los españoles. Por eso los incas, lejos de crear toda la civilización calchaquí que conocemos, ni la podían haber influído profundamente ni haber cambiado todos sus caracteres.

La pretensión de probar con pocos hechos sacados de la civilización de los incas, el origen de la civilización de los incas, el origen de la civilización calchaquí, debía provocar la resistencia de muchos de los arqueólogos argentinos; hay que disculpar por eso sus errores, cuando caen, en el otro extremo y niegan no solamente la influencia directa de los incas sobre esa civilización, sino también cualquier otra influencia que podría desprestigiar el origen completamente autóctono de las civilizaciones argentinas.

Se puede dar un paso hacia adelante y salir de este juego, con términos generales. Si hubo influencias de una de las civilizaciones sobre la otra, éstas han sido individuales según el tiempo y según las civilizaciones que las ejercían. También hay que probarlas según los objetos, formas, técnicas y ornamentos que se comparan. Por eso hay que distinguir primero, cronológicamente, 
las diferentes etapas de desarrollo que en ambas partes hubo. Pero habiéndolo hecho, estamos en aptitud, en todo sentido, de hacer las comparaciones necesarias, con el fin de determinar la extensión y la calidad de las relaciones en el transcurso de los períodos.

Sorprende mucho que la arqueología argentina, que no ha dado obras excelentes sobre exploraciones metódicas hechas en el interior del país, no haya llegado todavía á establecer una cronología, aunque preliminar, del desarrollo de estas civilizaciones antiguas.

Tal cronología es relativamente fácil, dado el contacto de los incas con la fase final de las antiguas civilizaciones argentinas. Encontramos en muchas partes artefactos incaicos al lado de otros de origen local, como en la ciudad de La Paya, en algunos entierros vecinos de Chañaryaco, y en muchos otros lugares. Entierros que contienen objetos incaicos al lado de otros de carácter nativo, son caracterizados, por esta circunstancia misma, como pertenecientes á los últimos ciento ó ciento cincuenta a los del desarrollo calchaquí, y definen individualmente el tipo de la civilización argentina en la última época prehispánica. Entierros ó cementerios enteros que no contienen ni vestigio de la civilización de los incas, son sospechosos por sí mismos, pueden remontarse á períodos anteriores y esta sospecha se convierte en realidad si los tipos representados difieren categóricamente de los entierros entreverados con objetos incaicos. Es igualmente tan falso considerar los objetos de esta última clase como curiosidades importantes indirectamente de provincias peruanas, como creer que todos los entierros de La Paya son representantes de una sola época. Las poblaciones antiguas, determinadas por las condiciones naturales, no cambiaban tanto de asiento. Por eso, lo que podría parecer excepción, es decir qie en un mismo lugar se encuentran reliquias de diferentes siglos y períodos, es más bien una regla, y es deber del arqueólogo atender cuidadosamente á todos los indicios que pueden enseñar de esta manera lago sobre diferencias cronológicas.

En la ciudad de La Paya ${ }^{1}$ los siguientes entierros contenían objetos incaicos:

Números 46, 61, 63, 72, 73, 74, 116, 128, 161, 165.

Resulta de eso que, entre otros tipos, tazas de carácter campanuliforme, como el número 1038 (del entierro 61) ó taza de ángulos grandes, como el número 1921 (del entierro 165) ${ }^{3}$, ó vasos de forma no común, como los números 829, 1382 y 1383 (de los entierros 72 y 74) ${ }^{4}$, tienen relación, cronológicamente, con la época incaica de la Argentina, y pertenecen por eso á la última etapa de la civilización argentina en general. Naturalmente, una separación completa de los tipos de diferentes épocas no se puede efectuar sino en presencia de los objetos mismos, y no con la descripción general de los hallazgos encontrados durante las exploraciones. Pero el hecho de que tipos como los números $829,1038,1382,1383,1921$ se usaban todavía en la época incaica, despierta la sospecha de que también entierros como los números $8,27,32,87,102$, $104,117,133,139,173,174,185,189,193,198$, acompañados de vasos parecidos, pertenecían á los tiempos cercanos de la época citada. Parece que la ornamentación con klimankistrones de línea redonda se usó más en tiempos recientes que en tiempos antiguos, y no lo contrario; este hecho ayuda la determinación cronológica de varios de los tipos representados. Pero el hecho más importante, me parece, es que las urnas funerarias de estilo de Santa María y de otros relacionados, cayeron en desuso en el tiempo incaico ó tal vez antes. Esta enseñanza que nos dan los cementerios de La Paya, coincide con el hecho de que los cementerios respectivos de Santa María, Pampa Grande y otros, no presentan ni rastros de objetos incaicos.

Es pues necesario, distinguir dentro de la civilización calchaquí, un período preincaico y otro más moderno que se extendió hasta la entrada de los incas en la Argentina. En La Paya, entierros como los números 35, 57, 62, 160,166, 167 y otros, me parece, remóntanse á aquel período más antiguo.

\footnotetext{
1 Juan B. Ambrosetti, Exploraciones arqueológicas en la ciudad de La Paya. Buenos Aires, 1907.

2 Ibidem, figura 144.

3 Ibidem, páginas 251 y 322

4 Ibidem, página368.
} 
Queda por definir la época de los vasos draconianos, tan lúcidamente tratados por el señor Lafone Quevedo.

Este arqueólogo eminente encontró cerca de Chañaryaco tres clases de tipos, representantes de diferentes períodos: entierros de la época incaica, vasos pintados, por su carácter contemporáneos con las grandes urnas funerarias de Santa María ${ }^{5}$, y muchos fragmentos de vasos draconianos, en parte pintados, en parte grabados. Esta trinidad de tipos significa al mismo tiempo una trinidad de períodos. Vasos de la última clase se han encontrado también en la región de Santa María, pero fuera de entierros del tipo preincaico de los valles clachaquíes. También faltan las relaciones en la ornamentación entre los vasos de aquéllos y éstos. En todo el desarrollo de las civilizaciones calchaquíes no hay punto que presente relación ó parentesco con el carácter especial de los vasos draconianos. Estos son enigmáticos, tanto como tipo, en relación con los otros, como por extrema rareza y la dificultad de encontrarlos. No se han hallado todavía cementerios enteros que los representen no se han podido establecer reglas sobre las condiciones en que se encuentran en el suelo. Todo habla en favor de una antigüedad extrema, superior á la de los conocidos vasos de Santa María. Por eso me creo autorizado á condenarlos como los tipos más antiguos, representantes de un período que precedió á los tipos conocidos de la alfarería calchaquí.

Según la exposición anterior, la alfarería antigua del noroeste argentino, representa tres períodos diferentes de desarrollo:

1. El período de los vasos draconianos ${ }^{6}$;

2. El período preincaico de los vasos propiamente calchaquíes, como en los cementerios de Santa María, Pampa Grande, Amaicha, etc.;

3. El período incaico, incluyendo las últimas fases del desarrollo argentino que le precedió.

Por el lado del Perú, para recapitular resultados ganados en otro lugar tenemos:

1. El período de la civilización de Proto-Nazca y Proto-Chimú (con dependencias, como Proto-Lima, Proto-Chancay y otras);

2. El período de la civilización de Tiahuanaco (con dependencias y civilizaciones variadas en diferentes partes del país);

3. El período de los incas.

Comparando ahora las diferentes civilizaciones peruanas y argentinas, no se pueden poner en paralelo naturamente la civilización de los incas con el segundo período argentino, no Proto-Nazca ó Proto-Chimu con el mismo, etc. Aunque no tengamos ninguna prueba de la absoluta contemporaneidad del primer período peruano con el primero argentino, será lícito buscar los puntos de contacto más ó menos en este sentido, y si se encuentran semejanzas, el hecho mismo de una contemporaneidad relativa reforzará el peso de una probabilidad de relaciones, eventualmente capaz de levarla sobre las simples suposiciones.

1. El periodo del salvajismo.- Hablando de una manera exacta no se puede excluir de las relaciones prehistóricas entre los dos países las que hubo en el estado del salvajismo y antes de los principios de la civilización al menos en uno de los dos países. Los habitantes primitivos de la altiplanicie boliviana nos son incompletamente conocidos y de sus lenguas no nos han

5 S.A. Lafone Quevedo, Catálogo de las huacas de Chañaryaco. Revista del Museo de La Plata, III, 1892 , figura 19. Compárese también F.F. Outes, Alfarerías del noroeste argentino. Revista del Museo de La Plata, $2^{\mathrm{a}}$ serie, I, plancha IV y página 37 .

6 Compárese especialmente Lafone Quevedo, Tipos de alfarería calchaquí. Revista del Museo La Plata, tomo VI; Huacas de Chañaryaco, páginas 15 y siguientes; Viaje arqueológico en la región de Andalgalá, ibídem, tomo XII: 
quedado más vestigios que la lengua de los Uros que todavía se habla en algunos pequeñísimos distritos. La lengua antigua de los valles calchaquíes es hasta ahora desconocida. Por eso no sabemos nada sobre relaciones lingüísticas entre los habitantes del Altiplano de Bolivia y los de los valles que bajan hacia el sur, en la Argentina. Pero mencionaremos que los Uros en tiempos primitivos deben haberse extendido desde Lipes, donde fueron encontrados en el período de la conquista y donde legaron el tipo de una pequeña raza parecida, hasta el lago Titicaca y toda aquella región de lagos y lagunas que en parte se han secado, ó como el lago Titicaca, desde un número indefinido de siglos ${ }^{7}$ permanecen inalterados.

La lengua de los Uros parece haber tenido relaciones antiguas de vecindad con las lenguas de la raza Gez-Cren, según la semejanza de su palabra qoási con la de aquellas lenguas ${ }^{8}$. Parecida es también la palabra araucana co que dice agua, confirmándose de esta manera relaciones con laguna de las naciones que vivían al sur. Las relaciones con la lengua atacameña son poco numerosas.

La lengua Uro, en su organismo fundamentalmente diferente del aimará y quechua. Tiene relaciones de palabras al menos con algunas de las lenguas de las faldas orientales de los Andes, como el Mosetene y Movima ${ }^{9}$. Fuera del Mosetene y Movina las relaciones de palabras con las de otras lenguas son escasas. Sin embargo, merece ser mencionado que como en el Uro el ojo se llama chuqe, así se llama chu, en el Lule (según Machoni), toque, en Vilela (según Gili), tacqui, en Chunupí (según Fontana), ge, en el Araucano, y que como qoya es la palabra que expresa casa en Uro, uyâ en Lule ${ }^{10}$.

Me parece ser muy notable que las palabras Uro tsoñi por hombre, tuñi por sol, qoya por casa, kunni por oreja y algunas pocas más, tienen paralelas no muy lejanas en dialectos patagones. Por ejemplo, según Musters, los patagones se llamaban tsónica, para significarse como hombres y chuina ó shuim ha sido indicado por varios como su palabra para expresar sol. Á Uro qoya, casa, correspondería patagón kou ó cocha, y á kunni oreja, coana ó jene, shene, según diferentes vocabularios ${ }^{11}$. Aceptando estos paralelos como fundados, quedarían siempre como explicación posible las relaciones indirectas mediante otras lenguas orientales como el Movima ó Mosetene que participan en las mencionadas paralelas. Pero tales semejanzas además de ser interesantes por indicar relaciones con dialectos orientales de ubicación mucho más septentrional, que de otra manera no se explican todavía, nos indican al mismo tiempo que naciones primitivas de la altiplanicie no estuvieron nunca en sus asientos tan recluídas para no haberse comunicado con otros de los valles y planicies orientales, relaciones que directa ó indirectamente podían estenderse hasta tribus meridionales.

7 Uhle, Verhandlungen der Gesellschaft für Erdkunde zu Berlin 1894, página 328.

8 Cayapo: inkó; chavantes: keu; cherentes: kou; chicriabas: ku; apinages: inko; aponegicran: ko; cavacho: ko (v. Martius, Beitr. Z. Ethnogr. U. Sprachenk. Bras. 1867, II, pag. 134-151). Compárese también caingang: goio (Lafone Quevedo, La raza pampeana, pág. 88.)

9

\begin{tabular}{|c|c|c|c|}
\hline & Uro & Mosetene & Movima \\
\hline Hombre............. & luqu & & laqua \\
\hline Hombre.............. & soñi & zoñi & \\
\hline Oreja................ & kunni & choñ & \\
\hline Sol.................... & tuñi & tsuñ & tino \\
\hline Agua................ & qoasi & ojñi & \\
\hline Fuego............... & uji & tsi? & uoche \\
\hline Casa.................. & qoya & & droya \\
\hline $1 \ldots \ldots \ldots \ldots \ldots \ldots$ & sinda & zrit & \\
\hline 3....................... & chep & chibbin & \\
\hline
\end{tabular}

10 Brinton, The american race, página 364-365.

11 Compárese Daniel G. Brinton, Studies in American languages, p. 49. Compárense también en el lugar citado las palabras respectivas: nariz (uro: osa), mano (uro: qara), hombre (uro: luqu), mujer (uro: tkun), y otras. 
2. Período de la alfarería draconiana.- La civilización de la alfarería draconiana en la Argentina está representada por vasos pintados y grabados, fragmentos de ellos y un gran número de objetos de piedra, labrados todos, en cuanto se sabe, reunidos en las colecciones del Museo de La Plata.

Al movimiento general de los antiguos estilos peruanos corresponde de una manera sorprendente el que se observa en la evolución de los estilos del noroeste argentino. Á las figuras de concepción muy libre de Proto-Nazca y Proto-Chimu corresponden las de los vasos draconianos; en la Argentina, figuras de concepción no menos libre á las figuras severas de Tiahuanaco, bien pueden ser comparadas.

El estilo Tiahuanaco, se repite de una manera muy parecida en la alfarería preincaica calchaquí, y su carácter pronunciado se modera á medida que se acerca de los siglos inmediatos de la civilización de los Incas.

Cualquiera que haya visto el caso de Blamey $^{12}$ (fig. 1) se habrá quedado sorprendido por su extraordinaria finura técnica, formal y decorativa que no tiene rival en ningún producto de períodos posteriores de noroeste argentino. En todo eso se o puede comparar, como otros parecidos, sólo con vasos de Proto-Nazca y quizá también de Proto-Chimú. La figura de su ornamentación al lado de las típicas de Proto-Nazca (fig. 2) sorprende por el paralelismo de sus caracteres generales. En ambas, la base de la decoración está formada por un dragón vermiforme que consiste de un cuerpo arbitrariamente torcido y provisto de extremidades laterales y de una cabeza sobrepuesta, vista de frente y de carácter semihumano.

La forma y la ornamentación fantástica de las caras también puede servir para la comparación. El canal estomacal del verme, en Proto-Nazca se halla rellenado con caras de diferente carácter ó con bolitas, y en las figuras draconianas argentinas reemplazado por un relleno consistente en óvalos el ornamento de cuello del vaso Blamey se repite un modo muy parecido en vasos de ornamentación geométrica de Proto-Nazca. Las grandes semejanzas en ambos, de carácter general, preponderan sobre los puntos de diferencia que, por otra parte, no faltan.

Otros vasos draconianos muestran figuras con caras monóculas sumamente fantásticas cuya impresión general recuerda las caras monóculas igualmente fantásticas en muchos de los vasos de Proto-Nazca.

Los vasos grabados del tipo draconiano argentino presentan otras tantas paralelas que tampoco deben pasar desapercibidas, como las colas de los animales que terminan en cabezas de serpientes ${ }^{13}$, detalle repetido de una manera muy parecida en innumerables figuras de los vasos Proto- Nazca y Proto-Chimú (compárese también fig. 4); la representación plástica de una mujer que carga un vaso $^{14}$, motivo por sí mismo difícil en una alfarería incipiente, pero que corresponde á muchos figuras del mismo carácter de aquellos períodos; los gorros representados en figuras humanas (piel de un gato con proyección de su cabeza adelante y dos triángulos sobresalientes encima, fig. 3) idénticos en su forma con los representados en muchos vasos Proto-Chimú (fig. 4-7).

Es difícil creer que tantas semejanzas cercanas pudiesen haber tenido por fondo sólo paralelismos casuales.

El estilo draconiano en la Argentina habrá sido de toda manera de origen extraño. Así sólo se explica la rápida transformación de las figuras draconianas competas, en un estilo zoomorfo (Thierornamentik) que muchos de los vasos demuestran. Tales estilos, caracterizados por la desmembración de las figuras y la repetición continua de sus partes como elementos de otros ${ }^{15}$, suelen ser la consecuencia de la transplantación de estilos figurativos de regiones de mayor civilización, á otras de cultura más baja. Las figuras no fueron entendidas en el nuevo ambiente y por eso degeneran desubstanciándose, y sobreviven sólo en partes desmembradas que se repiten, combinadas, con otras de diferente sentido.

\footnotetext{
Compárese S.A. Lafone Quevedo, Tipos de alfarería calchaquí, página 363.

Lafone Quevedo, Tipos, plancha V.

Ibidem, plancha XI

Soph. Müller, Die Thierornamentik in Norden. Uebers. Von J. Mestorf, 1881, página 4 y siguientes.
} 

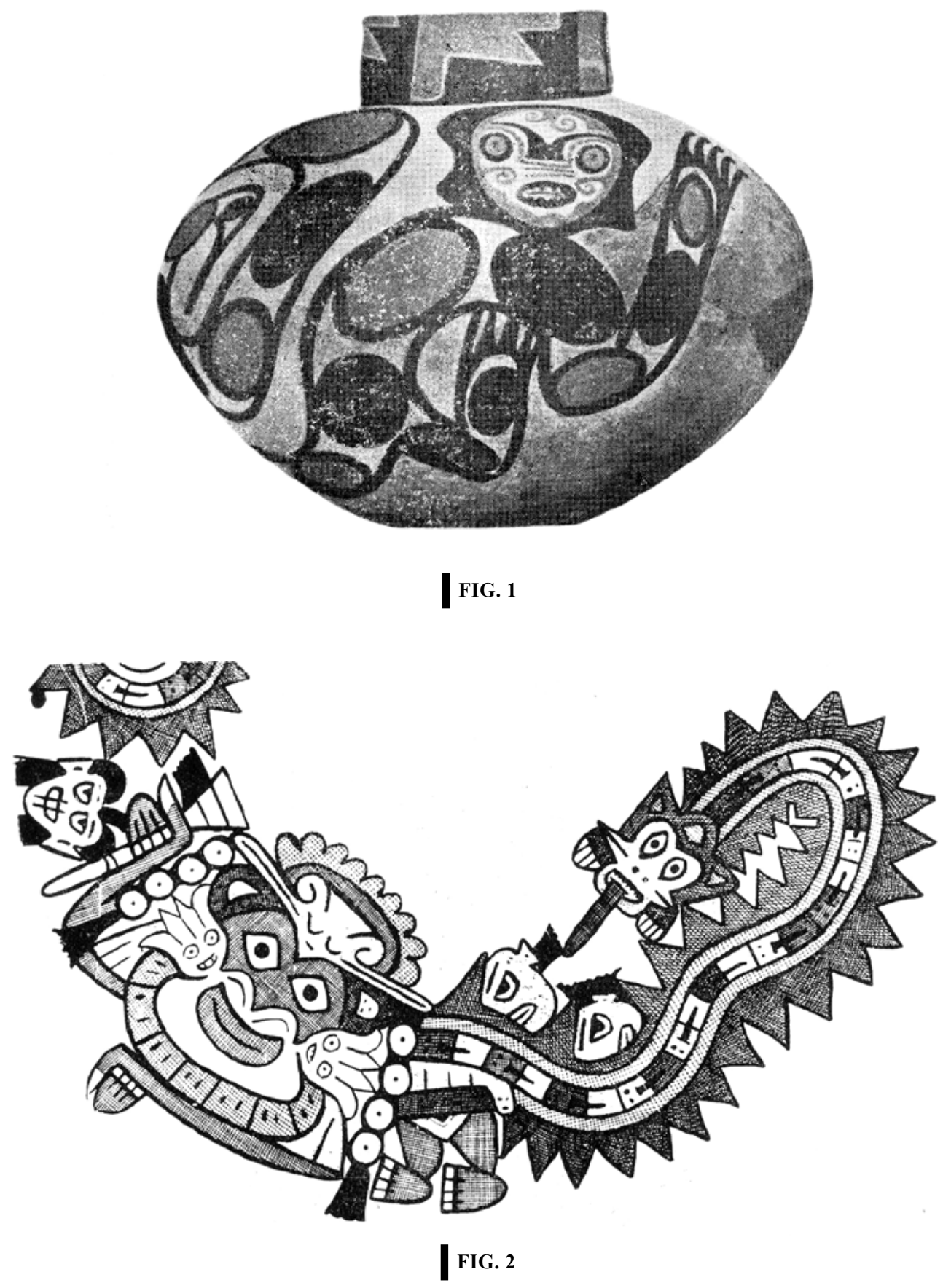

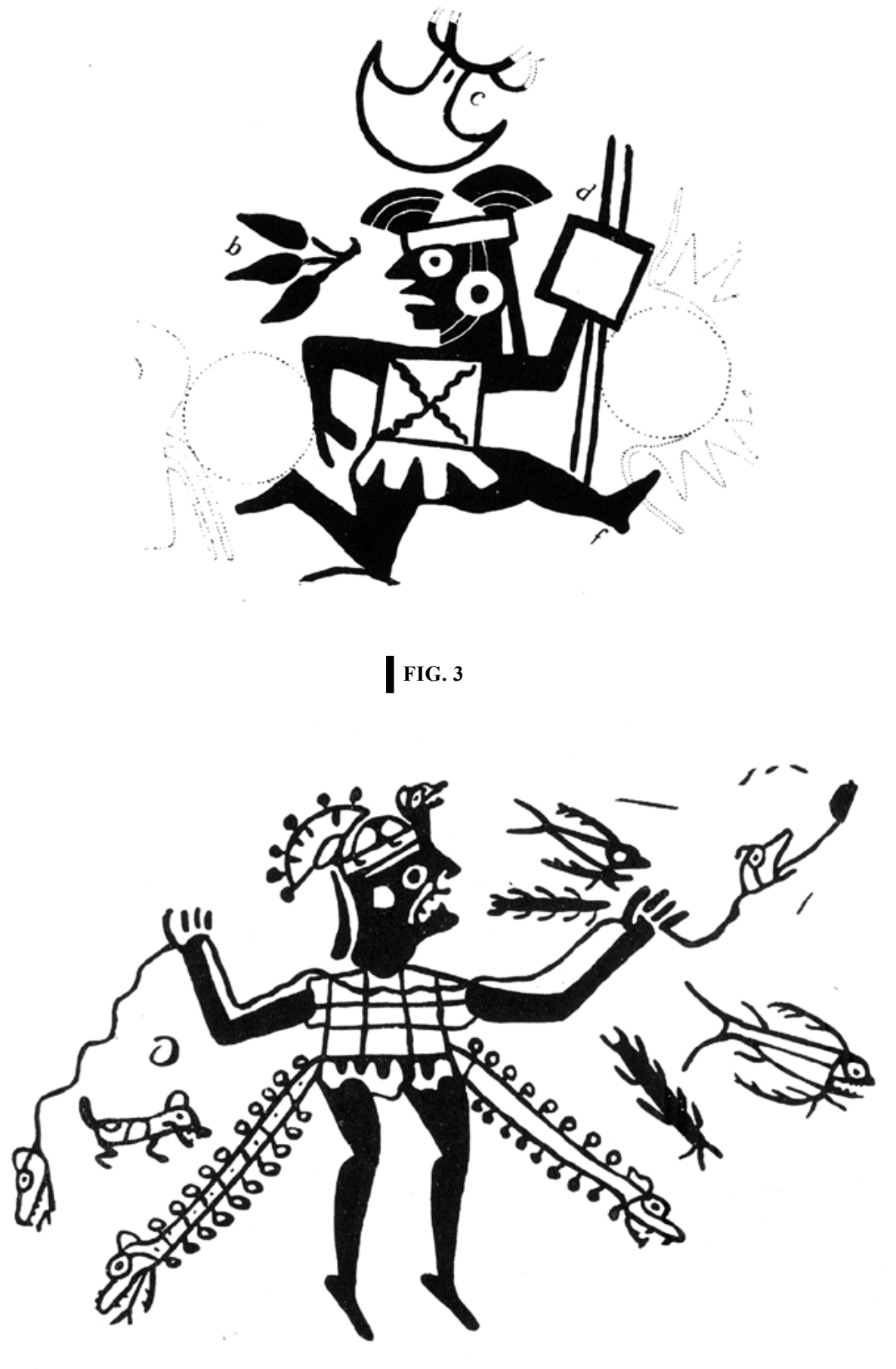

FIG. 4 


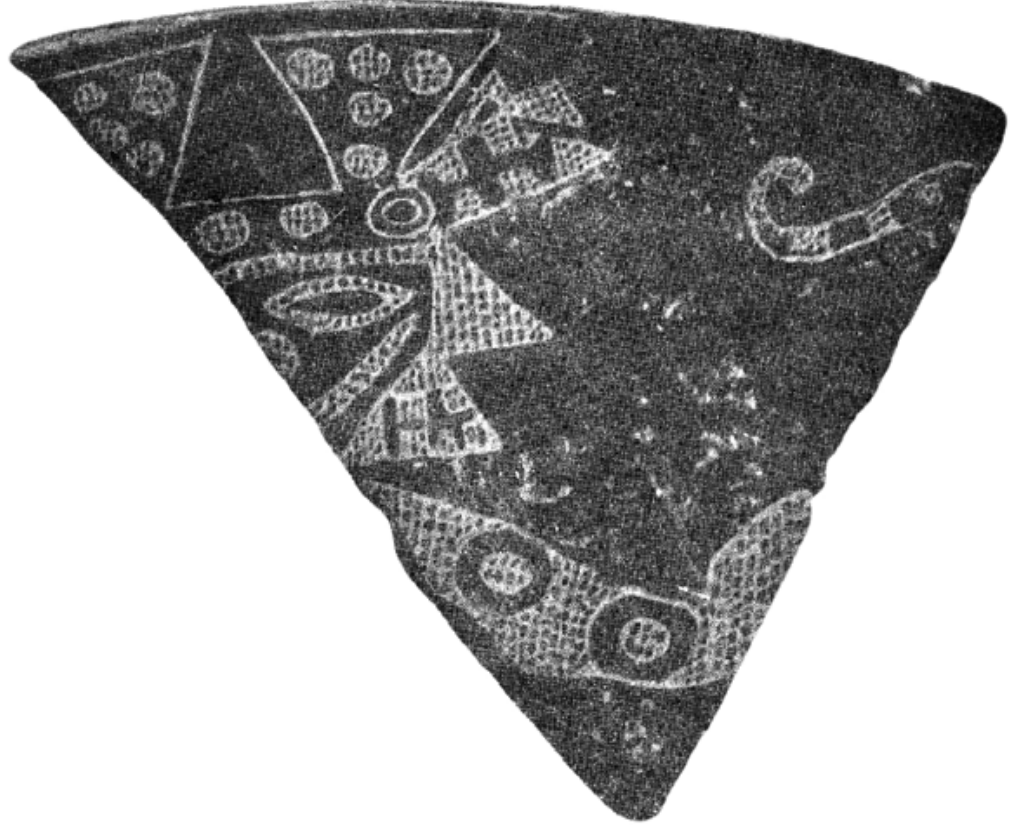

FIG. 5

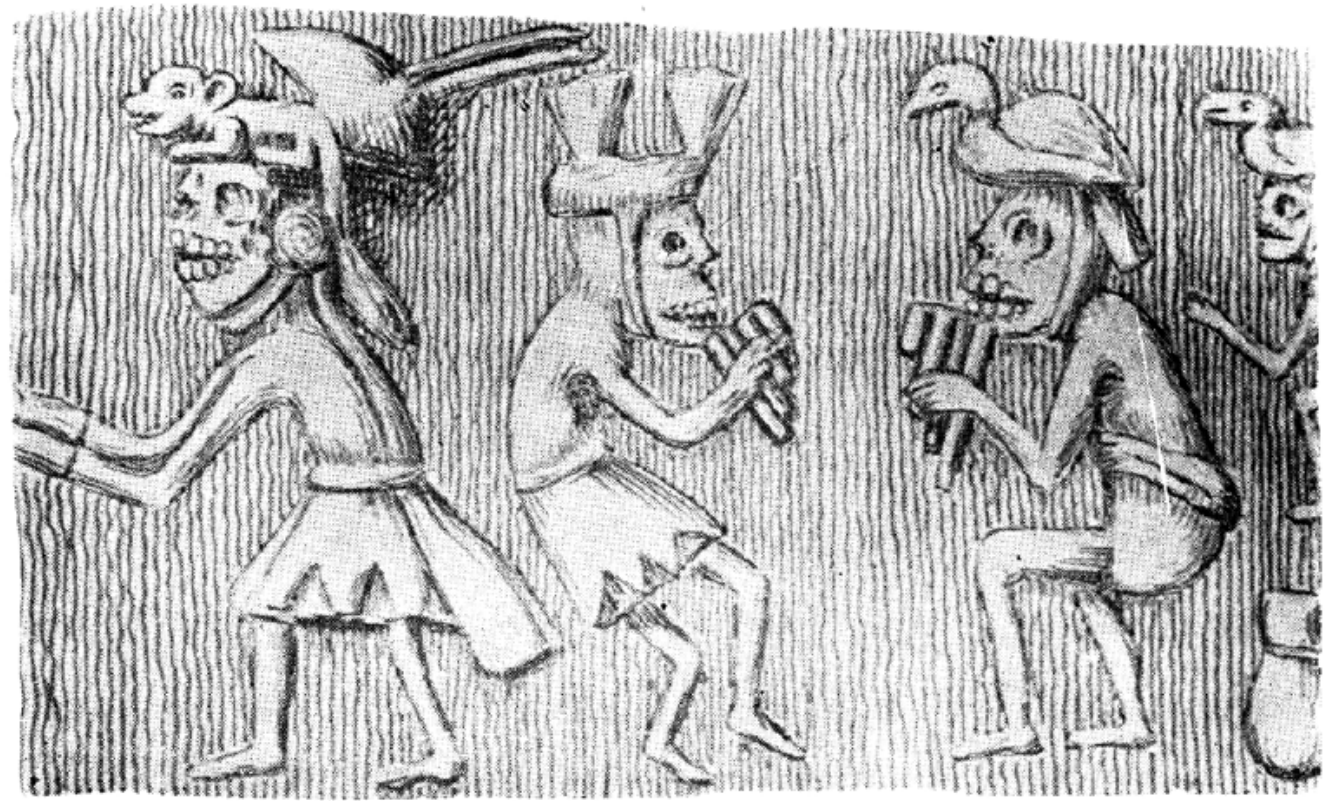

FIG. 6 


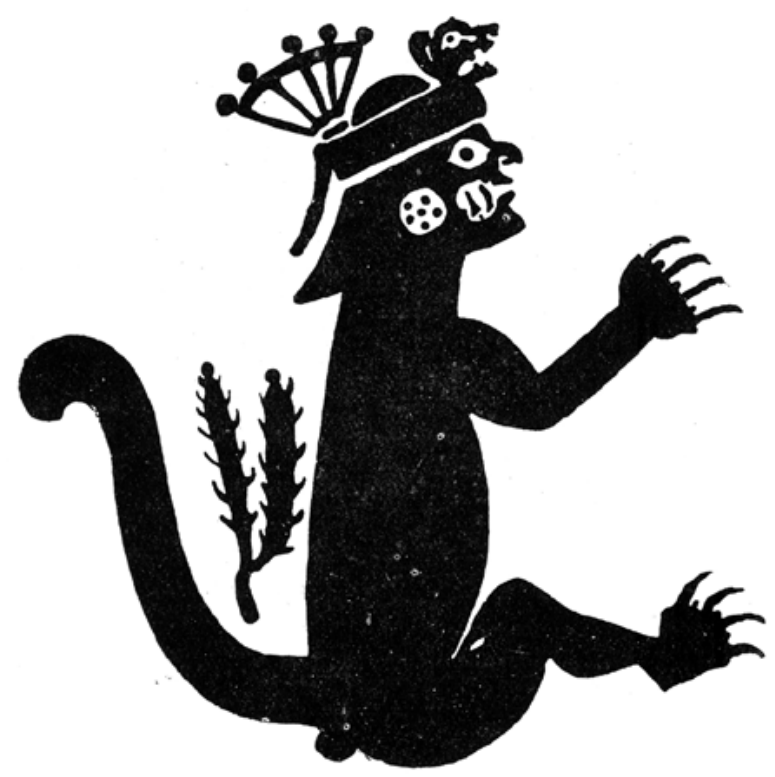

FIG. 7

En su Viaje arqueológico, el señor Lafone Quevedo, reproduce un fragmento de una taza grabada, de Tinogasta.

Idéntico en la técnica con los otros vasos draconianos, difiere de ellos en el estilo de su figura (fig. 8). Ésta por su parte tiene muchas semejanzas estilísticas y también en detalles con las representaciones del estilo de Tiahuanaco. Obsérvese la posición bastante equilibrada de la figura humana, su cara cuadrada; el arma bacilar y la cabeza humana como trofeo á su lado. Muy parecida es de este punto de vista la figura de un tejido hallado en Ancón y reproducido por W. Reiss y Stübel en la página 50 de su obra sobre aquella necrópolis (fig. 9).

Todas estas semejanzas y paralelas hablarían suficiente por sí mismas y en favor de relaciones antiguas, si la distancia más ó menos de 300 leguas entre los puntos finales, la región de Nazca y la provincia de Catamarca, no fuera un impedimento. Las antigüedades de todo el sudoeste sudamericano son conocidas sólo muy fragmentariamente. No sabemos qué descubrimientos en toda esa zona todavía nos esperan; por eso debemos aprender más bien de los hechos que formar teorías sobre distancias. Pero aunque faltan todavía, los eslabones intermedios, varios indicios nos enseñan que la ley de distancias ha sido quizá más exacta en el continente sudamericano que en otras partes del mundo. Doscientas, trescientas hasta quinientas leguas significaban á veces muy poco en las relaciones entre naciones sudamericanas.

Los Incas en sus conquistas de Chile y del Ecuador, vencieron distancias de 400 leguas. La civilización de Tiahuanaco llegó por el norte hasta la provincia de los Cañares, cerca de 300 leguas del punto de su origen ${ }^{16}$. Á Pachacámac peregrinaron los indios desde distancias de 300 leguas. Los Collahuayas con sus bolsas de medicina marchan todavía hoy día desde el norte

16 F. González Suárez, Historia general del Ecuador, 1892, Atlas, lámina II con página 57 (plancha de oro con representación de una de las figuras laterales de la gran portada de Tiahuanaco). 


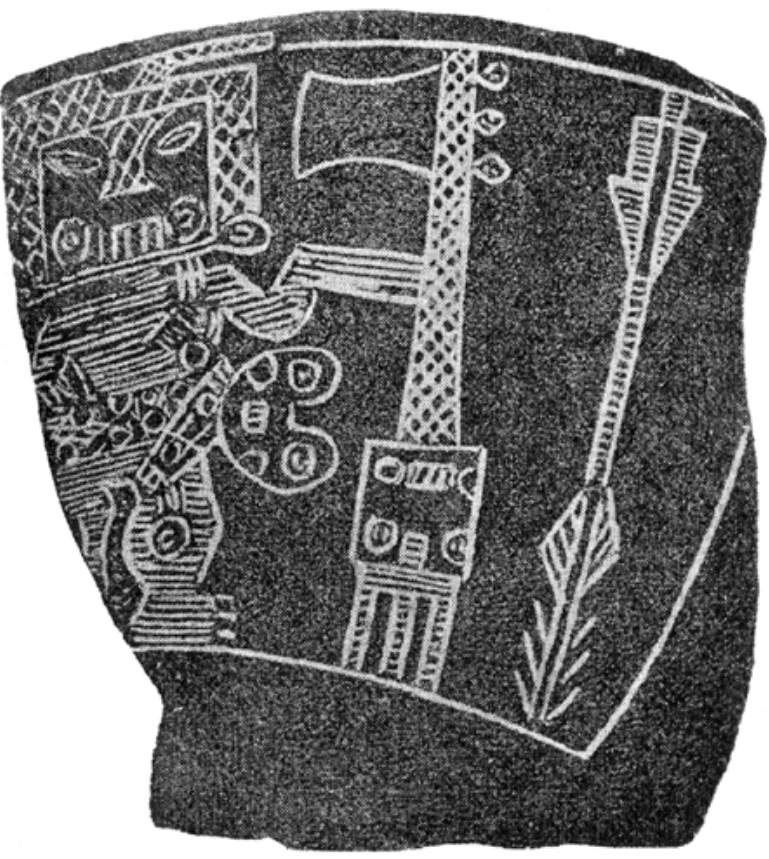

FIG. 8

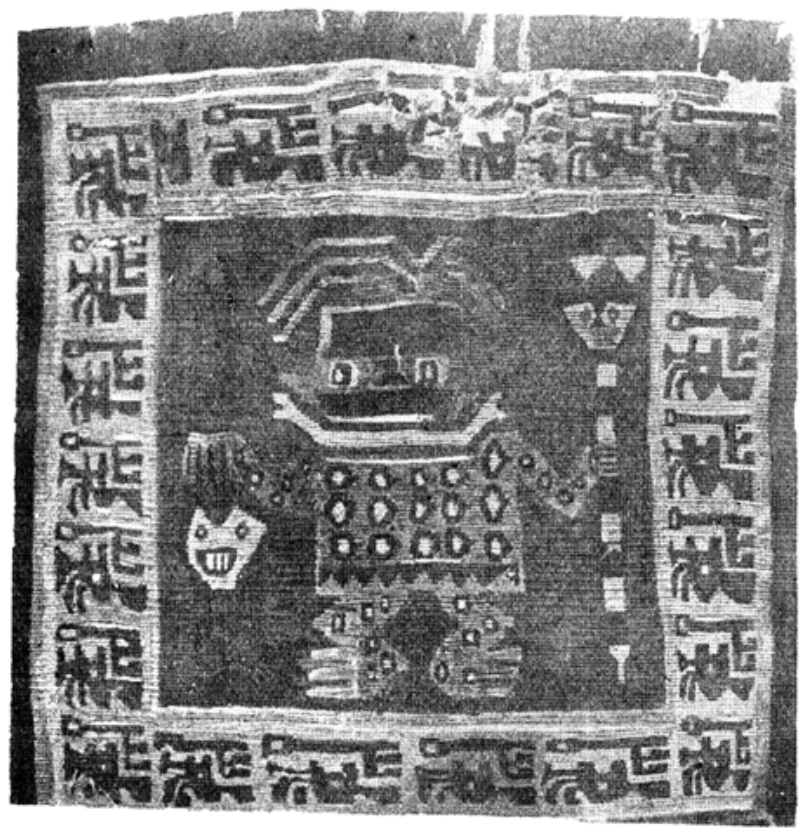

FIG. 9 
del lago Titicaca hasta Buenos Aires, recorriendo 450 leguas desde su punto de salida. Los Chimús importaron durante miles de años conchas y caracoles (Spondylus pictorum y Conus Fergusoni) de los mares tropicales, desde Colombia en el norte, distribuyéndoles después por toda el Perú hasta el sur lejano. Piedras para amarrar anzuelos de forma idéntica, se usaban en los valles centrales del Perú, por ejemplo en Pachacámac, como á distancias de 200 y 300 leguas en las costas chilenas ${ }^{17}$. Un vaso del período de Tiahuanaco encontrado en Copiapó ${ }^{18}$, es idéntico á los que constantemente se hallan en el valle de Lima; un vaso hallado en Pesorca ${ }^{19}$ es en su forma igual á muchos de los que proceden de los valles del norte del Perú.

Considerando todo esto no creo imposible que civilizaciones del antiguo Perú tan lejano hayan tenido influencia en los valles de la cordillera argentina y espero del porvenir la aclaración de los indicios que existen.

3. Período preincaico calchaquí.- Este período está caracterizado, como hemos visto, por los vasos, urnas tazas, etc., encontrados en los cementerios de Santa María, Quilmes, Amaicha, y otros parecidos. Se incluyen entre los objetos característicos de este período muchos objetos de cobre, como campanas, placas pectorales, discos, las más curiosas de las hachas y cetros de mando ${ }^{20}$, muchos objetos labrados de madera, como especialmente las "tabletas de ofrenda" y los "escarificadores", aunque es posible que algunos de los últimos han alcanzado el período incaico ${ }^{21}$.

El tipo más antiguo de los vasos parece el con ornamentación geométrica severa, como la urna funeraria representada por Lafone Quevedo, Tipos, plancha II (véase fig. 10, abajo) ${ }^{22}$, cuyos elementos principales de ornamentación son líneas escaleradas, fajas transversales acompañando á aquéllas y klimankistrones de línea recta. Es por eso un tipo muy parecido que se extendía en el período de Tiahuanaco hasta la región de Ilo (fig. 11) y Arequipa (fig. $12)^{23}$, y por el otro lado á la región de Atacama y á otras partes vecinas de Chile ${ }^{24}$. El área angosta y la relativa contemporaneidad de los objetos correspondientes que proceden de la Argentina y de la región limítrofe entre Boliviana y Peruana, hacen suponer que hubo relaciones antiguas.

Entre los objetos comunes Tiahuanaco faltan los de madera porque el clima desfavorable no los ha conservado, pero muchos objetos figurativo de madera, labrados en el estilo de esta localidad y conservados en las cementerios de la costa, nos dan la prueba de que otros iguales no habrán faltado en Tiahuanaco en tiempo antiguo. Representan generalmente animales místicos y figuras humanas en diferentes posiciones, muy parecidos á aquellos labrados en objetos de madera que se han encontrado en los entierros antiguos de la ciudad de La Paya. Por ejemplo, una figura como la reproducida en la figura 13, que fue encontrada en las ruinas de Gran Chimú, cerca de Supe, puede ser comparada muy bien, en muchos de sus detalles, con os ornamentos de objetos de La Paya y de Quilmes ${ }^{25}$.

17 J. T. Medina, Los aborígenes de Chile, 1882, figura 92.

18 Ibidem, figura 164.

19 Ibidem, figura 175.

20 Compárese J. B. Ambrosetti, El bronce de la región Calchaquí, Anales del Museo Nacional, tomo XI, Buenos Aires, página 236 y siguientes. Una de las hachas de mando fué encontrada en la Casa Morada. (Ambrosetti, Sepulcro de La Paya, Anales del Museo Nacional, tomo VIII, Página 123; compárese también Ambrosetti, La Paya, página 47.)

21 Así podría parecer según la descripción del contenido del entierro número 189 (La paya, pág. 269).

22 No me parece imposible que el tipo de urnas funerarias como el representado por el señor F. P. Moreno, en su Exploración arqueológica de Catamarca, Revista del Museo de La Plata, I, 1891, página 11, de Santa María, forma un eslabón de desarrollo intermedio entre los vasos draconianos y las urnas del tipo figura 10. Compárese la asimetría de la ornamentación. Hay aquí un problema que merece la atención de los arqueólogos.

23 Compárese también Kultur und Industrie südamerikanischer Völker, parte I, plancha 11, figuras 3.4, 10; plancha 11, figuras 7-9; plancha 25, figura 19; plancha 26, figura 3. De la región de Arequipa, en el Museo Nacional de Lima.

24 Compárese la colección del señor A. Echeverría y Reyes en Antofagasta; J.T. Medina, Aborígenes de Chile, Atlas, etc.

25 Ambrosetti, La Paya, figuras páginas 266, 276, 279, etc.; Notas de arqueología calchaquí, figura 25. 
DOCUMENTOS Y TESTIMONIOS | 139

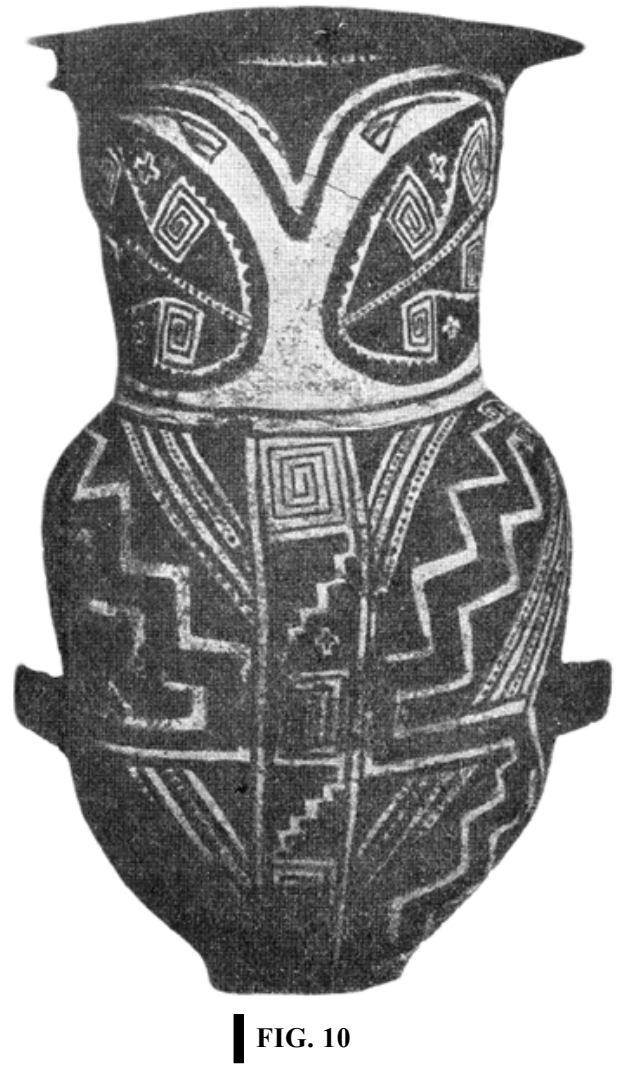

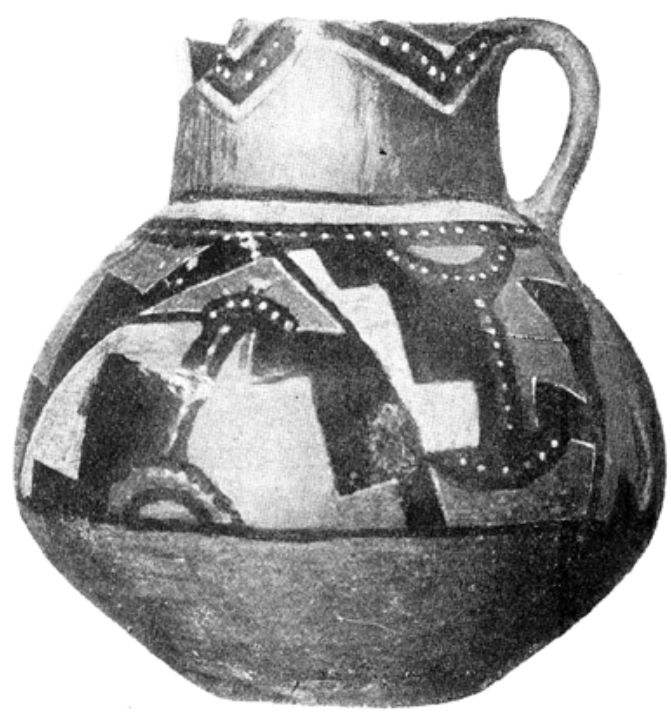

FIG. 11

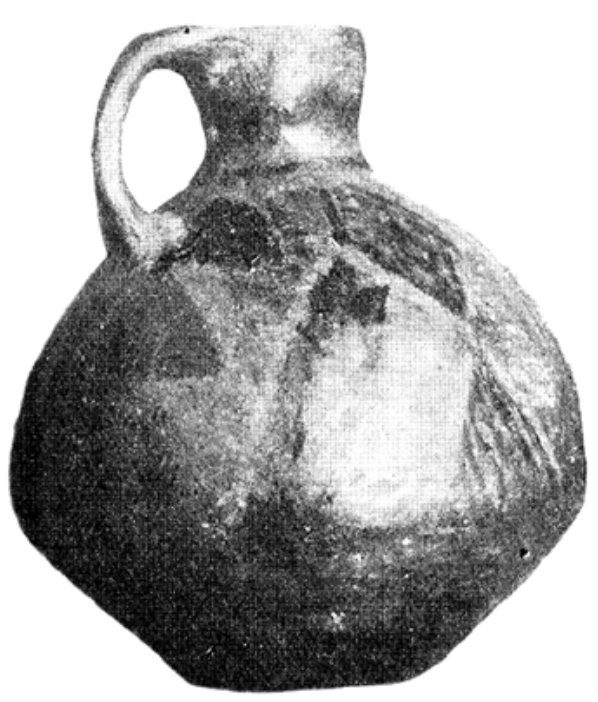

FIG. 12 


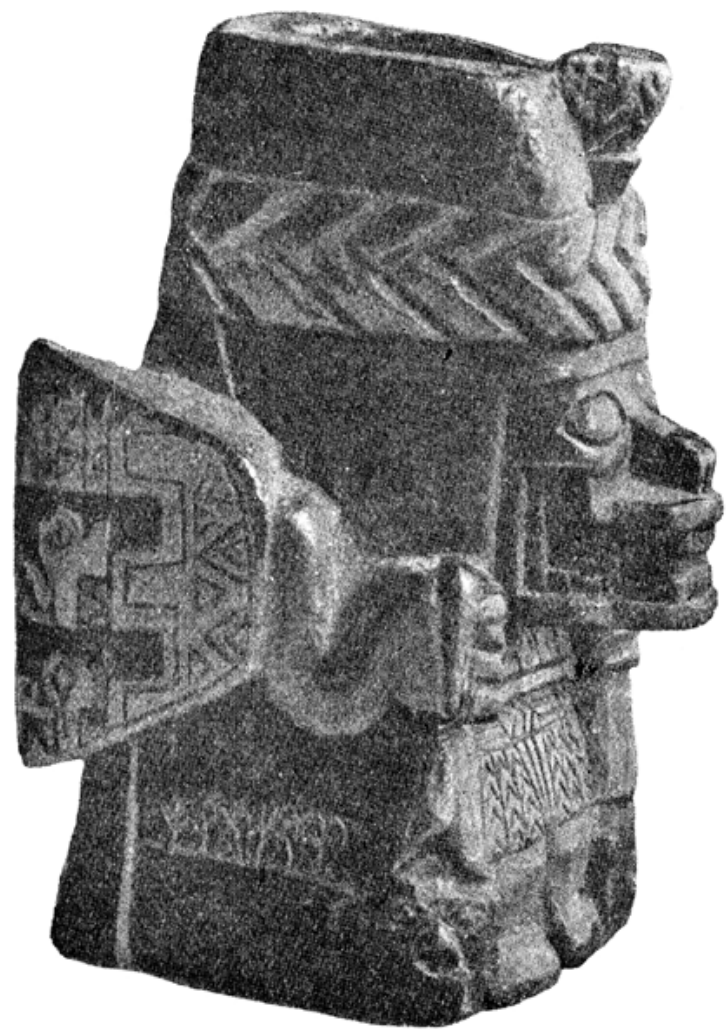

FIG. 13

Muy característica para objetos de este período argentino en madera y cobre, es una combinación de dos ó hasta de tres figuras ${ }^{26}$. Compárese también la figura $14^{27}$. Ésta nos recuerda estrechamente á las compisiciones simétricas con tres grupos de figuras que son características para Tiahuanaco, como por ejemplo, en el relieve de la gran portada, en un paño pintado de este período encontrado en Pachacámac ${ }^{28} \mathrm{y}$ otros.

La cruz, como símbolo religioso de dominio general en las antiguas civilizaciones americanas, aparece sin embargo sólo en algunos vasos de Tiahuanaco ${ }^{29}$ y en las figuras de un objeto de la Paya $^{30}$ sobre la frente de caras humanas.

En Tiahuanaco, en los valles Calchaquí (La Paya, Quilmes, etc.) y en Atacama, se usaban tablitas chatas de forma rectangular de madera y piedra que el señor Ambrosetti ha llamado "de ofrendas". De Tiahuanaco se conocen de éstos hasta ahora cuando menos ocho, todas de piedra gris, con mango ancho, chato, grabado en el estilo de aquellas ruinas (ejemplo figuras 15-16) ${ }^{31}$.

26 Ambrosetti, La Paya, figuras páginas 208, 501, 506; el mencionado objeto de Quilmes (Notas, fig. 25); Bronce calchaquí, figuras páginas 273-278.

27 Una placa pectoral entregada por el autor al Museo de Berlín.

28 Uhle, Pachacámac, plancha 4, figura 1

29 Kultur $u$. Industrie, parte I, plancha 11, figura 2 y otras.

30 Ambrosetti, La Paya, figura 271.

31 Debido á la amabilidad del director señor Haathal puedo reproducir aquí estos objetos del Roemer-Museum de Hildesheim. Se conocen dos que se encontraban en la colección del doctor Mazzei en La Paz, en 1894 (ahora probablemente en algún museo de Europa), dos mangaas quebradas de tablitas iguales en el Museum of Science and Arts en Phildelphia (Colección "Uhle" de Tiahuanaco), una adquirida por el doctor Debenedetti en La Paz, 1910, otra que se encuentra todavía en Oruro, etc. 


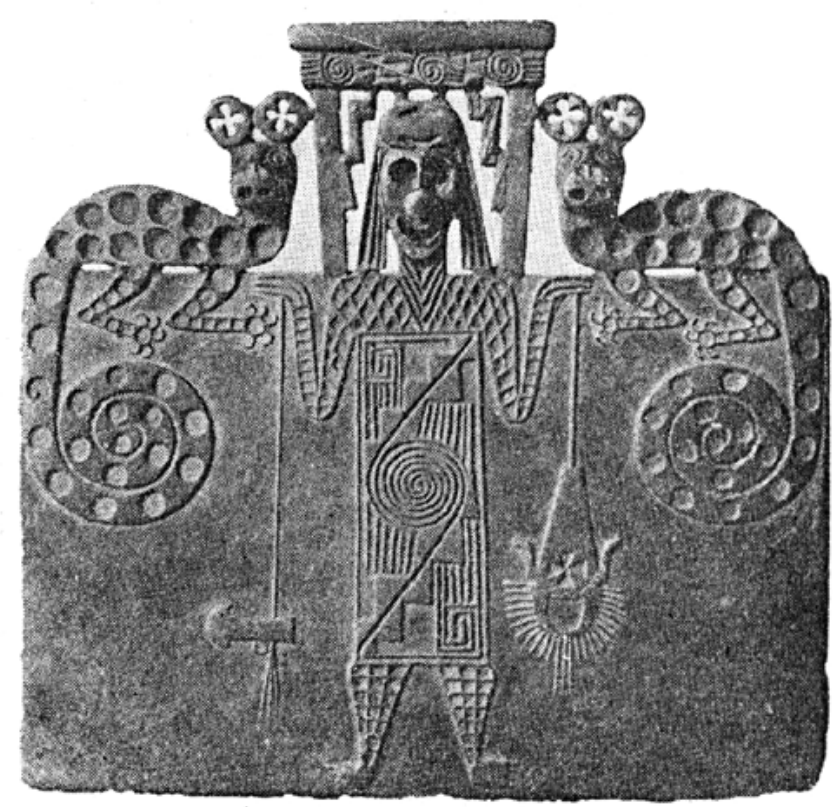

FIG. 14

Tablitas de forma completamente idéntica, pero de madera y sin los ornamentos grabados, se han encontrado en la región de Atacama ${ }^{32}$, quizá también en el noroeste argentino, lo que prueba lo estrecho de las relaciones entre Tiahuanaco y aquellas provincias meridionales en el uso de aquellos objetos. Puede ser que hubiese también en Tiahuanaco tablitas de madera con figuras labradas, como los correspondientes objetos argentinos. Pero la destrucción de todos objetos de madera en Tiahuanaco y la falta de las tablitas en los cementerios de la costa peruana ${ }^{33}$ hacen imposible averiguarlo.

Con mucha razón comparó el señor Boman las tablitas más grandes de madera usadas por los Mundurucús34 en el Brasil para moler narcóticos que después inhalan por la nariz, con las "tablitas de ofrenda" de la Argentina, pero con demasiada cautela se restringió á deducir de este paralelismo sólo el uso de las tablitas rectangulares argentinas para oler substancias macizas35. En mi trabajo sobre un tubo para tomar rapé hallado en Tiahuanaco, menciono el paralelismo que presentan, fuera de los instrumentos de primer orden (tubos), los instrumentos secundarios usados en el ejercicio de esta costumbre 36, y lo que no dije allá, es lo siguiente sobre el uso de las tablitas de los Mundurucús, lo cual explica por sí mismo, el de las tablitas rectangulares de Tiahuanaco, valles Calchaquí y Atacama; han servido para moler é inhalar narcóticos. El uso de narcóticos tomados por la nariz es positivamente comprobado en cuanto á varias partes de la Argentina, tanto en tiempo antiguo como en tiempo más moderno. Á esas regiones hay que agregar ahora los valles de la Cordillera. Á esta explicación no presenta dificultad la ornamentación figurativa de las tablitas, á la que Ambrosetti atribuye una significación religiosa, pues narcóticos, incluyendo el rapé, en muchas partes de América se

32 Una en el Museo Nacional de Santiago de Chile, y otra en Antofagasta en poder del señor Aníbal Echeverría y Reyes.

33 El señor E. Boman, Antiquités de la région andine, página 651, menciona una tablita de madera de una colección del Bajo Perú, indicación que sin definición más cara de la localidad escasea de valor.

34 Von Spix u. Von Martius, Reise in Brasilien, 1831, III, página 1318, con atlas, figura 61.

35 E. Boman, Antiquités de la région andine, París, 1908, página 653.

36 Bulletin of the Museum of Science and Art. Filadelfia, 1898, I, número 4, página 16, nota 1. 


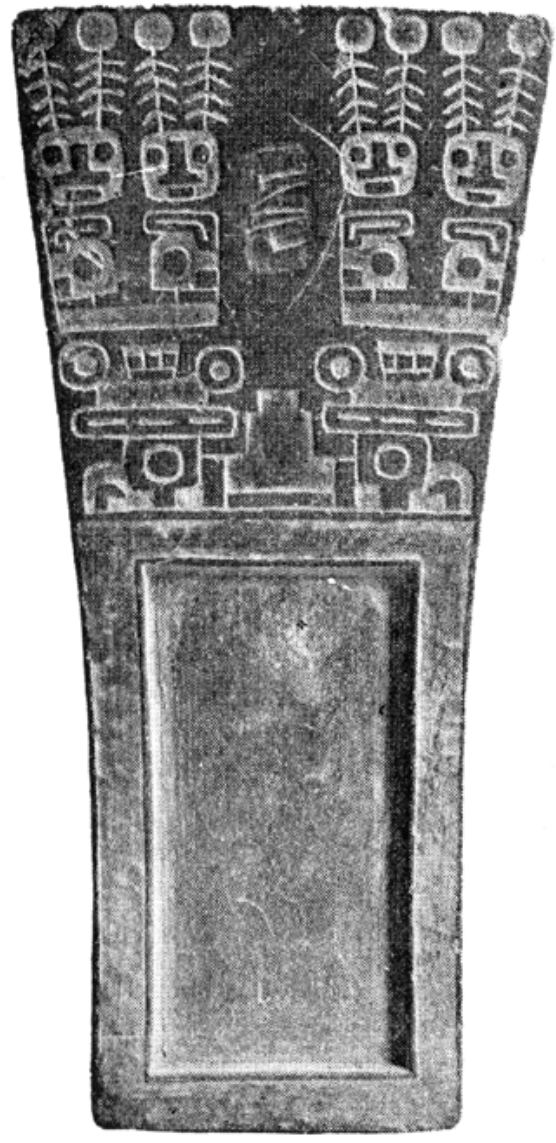

FIG. 15

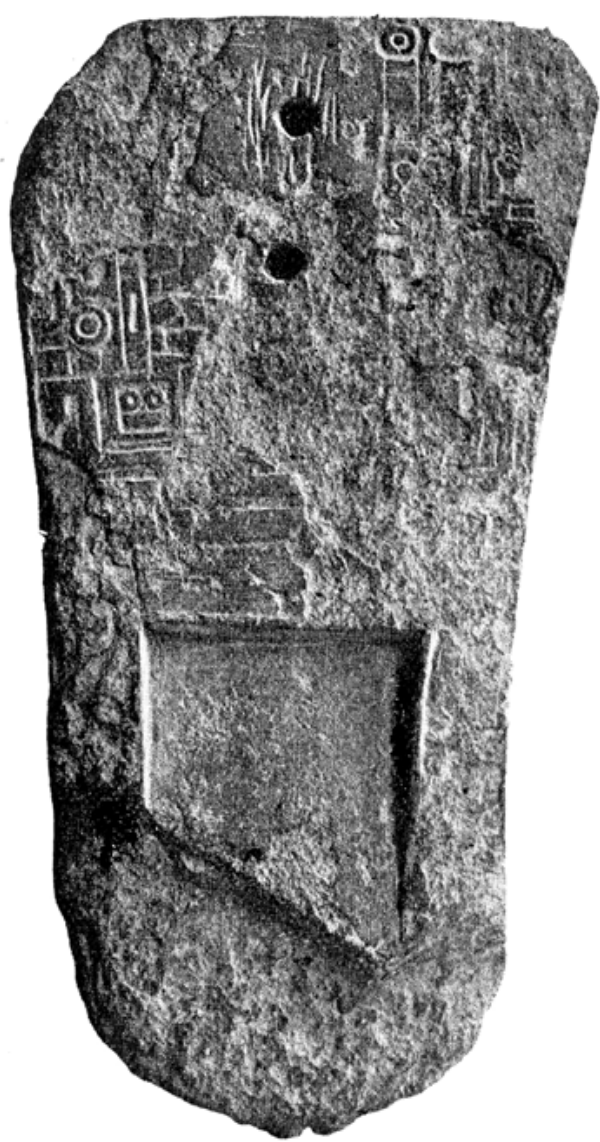

FIG. 16

usaron en los oficios religiosos para provocar alucinaciones, etc. Parece que en la Argentina faltan los tubos para tomar los narcóticos por la nariz, pero para Tiahuanaco, esta costumbre está comprobada por un ejemplar de hueso encontrado en aquellas ruinas. Pero del contenido de los entierros de La Paya descriptos por Ambrosetti, se puede derivar que la mayor parte de los escarificadores, instrumentos llamados así por Lehmann-Nitsche37 por ser desconocido su uso, fueron encontrados con "tablitas" de ofrendas" en los mismos entierros, lo que obliga á considerarlos como los instrumentos tubulares que faltan. Si quedan todavía algunas preguntas sobre el uso de los instrumentos de esta clase, su solución debe esperarse de investigaciones futuras que no afectan la determinación general de aquellos aparatos.

Las Memorias de Montesinos favorecen la idea de que naciones argentinas invadieron en un cierto período la altiplanicie boliviana. Tales invasiones de naciones del sur en provincias del norte, pueden haber producido un cierto acercamiento y relaciones entre las poblaciones argentinas y las de Tiahuanaco, pero no podrán explicar el desarrollo de la Argentina. Las civilizaciones peruanas, coherentes por su desarrollo entre sí mismas, tenían una base más

37 Lehmann-Nitsche, Catálogo de las antigüedades de la provincia de Jujuy, conservadas en el Museo de La Plata. Revista del Museo de La Plata, XI, 1899. 
amplia y probablemente también raíces más profundas en el Perú mismo que las del noroeste argentino en la Argentina. Además hemos visto que es mucho más probable que el período draconiano en la Argentina descienda de civilización peruanas que lo contrario. Á la invasión de tribus argentinas en Bolivia corresponde, por otro lado, un movimiento contrario, una entrada de Aimarás en la Argentina, garantizado por varios nombres geográficos que sólo se pueden explicar de esta manera. El cerro Aconcagua (mejor Ancocagua, según escritores chilenos) entre Chile y la Argentina, lleva el mismo nombre como un antiguo santuario aimará en la provincia de los Canas (región del valle del Vilconata) ${ }^{38}$ formado de aimara hanq'o, blanco, y cahua, que se repite en nombres aimaras de diferente carácter ${ }^{39}$. De origen parecido es el nombre de la sierra de Aconquija (mejor Anconquija, según Lafone Quevedo ${ }^{40}$, que contiene en su primera parte la misma palabra hanq'o, blanco, puesta sin duda por la blancura de la nieve. Nombres como Huachipas ${ }^{41}$, Pajsipas, Chuquiago ${ }^{42}$, Chicoana ${ }^{43}$, pueden ser de origen aimará y descendientes del mismo período, pero no son necesarias para corroborar la antigua entrada de los aimarás en la Argentina, suficientemente garantizada por aquellas etimologías.

4. El período de los incas.- Las pruebas de las influencias incaicas en la Argentina son tan numerosas y tan claras que no se le ocurriría á nadie ponerlas en duda ú obligar á otros á probarlas de nuevo, si el señor Ambrosetti no hubiese ensayado cambiar el rumbo de la cuestión, aseverando la importación, por Chile de los objetos que consideramos como incaicos. Para su aseveración se apoya en hallazgos de conchas marinas del Pacífico, encontradas en las mismas tumbas como los vasos incaicos, y en un supuesto estilo chileno de muchos de los vasos incaicos, comparando para eso un vaso hallado en Freirina ${ }^{44}$.

Aunque sería difícil entender cómo tales vasos incaicos, con ornamentación supuesta chilena, hubiesen llegado en tanto número precisamente á La Playa, á cuya latitud corresponde en Chile sólo el área seca ente Blanco Encalada y Taltal, se puede dejar esta cuestión aquí de lado. Más importante es que la presencia de conchas de Pacífico en entierros de La Paya, junto con vasos incaicos, probaría algo en favor de la importación simultánea, si estas conchas faltasen en otros entierros, especialmente más antiguos, lo que no es el caso ${ }^{45}$. El vaso de Freirina, hasta menos la existencia de un período de tal alfarería en Chile, cuanto que en todo su carácter, fuera de algunos detalles incaicos, corresponde á artefactos noroeste-argentinos del mismo período, y los detalles de el que para Ambrosetti parecen de tipo chileno, se repiten únicamente en vasos argentinos. El avestruz dibujado en el vaso de Freirina, es ahora el único hallado en algún objeto Chileno, mientras es típico para la alfarería calchaquí de todos períodos. Por eso es todavía más probable que el vaso de Freirina fuese importado de la Argentina á Chile, que asignarle origen autóctono chileno. Sorprende que el señor Ambrosetti considere los animales reproducidos en los vasos incaicos "de tipo chileno" como elementos de una ornamentación forastera después de haber reunido él mismo una manera tan ilustrativa todas las figuras parecidas del suelo argentino que puedan explicar su desarrollo en la Argentina ${ }^{46}$.

38 Cieza, Crónica del Perú, I, capítulo 98.

39 Compárese por ejemplo, Apocaua (nombre de un cacique), Informaciones acerca del Señorío (Colección de libros españoles raros y curiosos, vol. XVI) página 241. Véase también muchos nombres geográficos bolivianos con Anco, en Manuel V. Ballivian, Diccionario Geográfico de Bolivia, 1890, página 5 y siguientes.

40 Samuel A. Lafone Quevedo, Londres y Catamarca, Buenos Aires, 1888, página 211; Tesoro de catamarqueñismos, Buenos Aires 1898, página 27.

41 Lafone Quevedo, Tesoro, página 150; también nombre de hacienda y de una ciudad antigna en el valle del Rimac, antiguamente habitada por Aimarás.

42 Chuquiago, nombre antiguo de la ciudad de La Paz (major forma que Chuquiyapu).

43 Nombre de un pueblo en el país de los Canas. Cieza, obra cit., capítulo 98 (ahora Sicuani).

44 Ambrosetti, La Paya, etc., página 56 y siguientes, 281, 518.

45 Compárese, por ejemplo, el entierro bastante antiguo número 21.

46 Sepulcro de La Paya, página 142-143. 
Como elementos de ornamentación forastera en los vasos incaicos de La Paya, Ambrosetti considera las figuras de pescados en posición de brincar ${ }^{47}$ y las pequeñas figuras de cortas líneas en forma de $\mathrm{H}$ y E. Las primeras son un ornamento peruano muy común, existentes en muchos platos incaicos, en tejidos, en las pinturas al fresco del templo de Pachacámac ${ }^{48}$, etc. Las figuras en forma de $\mathrm{H}$ son un ornamento sumamente común en platos incaicos y representan rebaños enteros de llamas, cuya figura abreviada se puede reconocer en muchas de ellas $^{49}$. Probable es que las figuritas en forma de E tienen una significación incaica parecida, sea que representan llamas como las otras ú otro animal, como avestruces. De esta manera se ve que en todos los vasos llamados "de tipo chileno", no hay ningún elemento característico para producciones chilenas, y todo su carácter se analiza como una combinación de elementos incaicos con argentinos. En vez de probar, por su ornamentación, su importación de Chile, estos vasos son por eso mismo una de las pruebas más claras de las incipientes influencias del estilo incaico en las producciones indígenas.

Es posible sólo esta explicación de los vasos mencionados de La Paya. Su ornamentación representa tanto una combinación de elementos incaicos con indígenas de La Paya, como la que se ve en vasos de otras partes, por ejemplo en Tinogasta ${ }^{50}$, que son una combinación de elementos incaicos con otros locales. El origen chileno de los vasos de La Paya excluiría la posibilidad de que vasos incaicos de otras partes del país mostrasen otros caracteres locales.

La dominación de los Incas en la Argentina en el último siglo prehispano está probada por innumerables nombres geográficos que se refieren á ellos (Incahuasi, Camino del Inca, Río del Inca, Casa del Inca, Costa de los Reyes, etc.); por las numerosas noticias sobre la marcha de los Incas por la Argentina en su conquista de Chile (la única dirección por la que podían entrar en aquel país defendido por regiones despoblados en el norte); por la descripción del camino del Inca entre Talina y la falda oriental de la sierra cerca de Tucumán, por Juan de Matienzo ${ }^{51}$; por muchos otros vestigios de caminos antiguos, en su apariencia idénticos á los que se ven en muchas partes del Perú ${ }^{52}$; por fortalezas erigidas en puntos estratégicos, las más veces sobre el camino antiguo (como en Angostaco, Pucará, la "Casa del Inca" cerca de Chilecito) ${ }^{53}$; los restos de vasos incaicos, algunas veces muy numerosos, hallados en el recinto de aquellas fortalezas y de tamberías antiguas (Costa de los Reyes); y el número extraordinario de objetos incaicos esparcidos por todo el país en todos los puntos adonde los Incas según parece, han llegado. En el campamento incaico de los llanos de Chilecito ("Casa del Inca") recogí toda una colección extensa de fragmentos de vasos incaicos y una bola de piedra ${ }^{54}$; en una antigua población del río del Inca, cerca de Tinogasta, otra, junto con más de 60 puntas de flechas de materiales muy diferentes, muchos retazos de talleres de muy variadas clases de piedra, mucho fragmentos de crisoles usados en las fundiciones y cerca de una libra de plata en los diferentes estados de la fundición $^{55}$. Parece que una parte del mineral de plata cortado en las minas de la Famatina se fundió cerca del río del Inca. También en La Paya deben haber sido numerosos los fragmentos de vasos incaicos á juzgar por la cantidad de cabecitas de pájaros pertenecientes á platos que representa Ambrosetti ${ }^{56}$. Los objetos incaicos hallados en la Argentina, son bastante frecuentes y pertenecen á casi todas las categorías, por ejemplo:

47 Ambrosetti, La Paya, página 70.

48 Uhle, Pachacámac, página 21, figura 9.

49 Compárese Kultur und Industrie, parte I, plancha 12, figura 7, y muchos vasos de la misma clase en diferentes museos. Á la misma categoría pertenece el plato Kultur und Industrie, obra citada, plancha 11, figura 15.

50 Compárese la colección Uhle en el Museo de Berlín.

51 Relaciones geográficas del Perú, 1885, II, Apéndice, página XLI y siguientes.

52 Por ejemplo, el "camino del Inca" al sur de Tinogasta, que pasando la "Costa de los Reyes" conduce en la dirección de la Sierra Famatina, se parece en todo á caminos conocidos de los Incas en el Perú, como cerca de Huamachuco, en la quebrada del río de Pisco, cerca de Atiquipa, etc.

53 También la "Casa Morada" en La Paya es según su tipo de construcción (especialmente los nichos) de origen incaico.

54 En el Museo de Berlín.

55 Todo en el Museo de Berlín.

56 Ambrosetti, La Paya, página 293. 

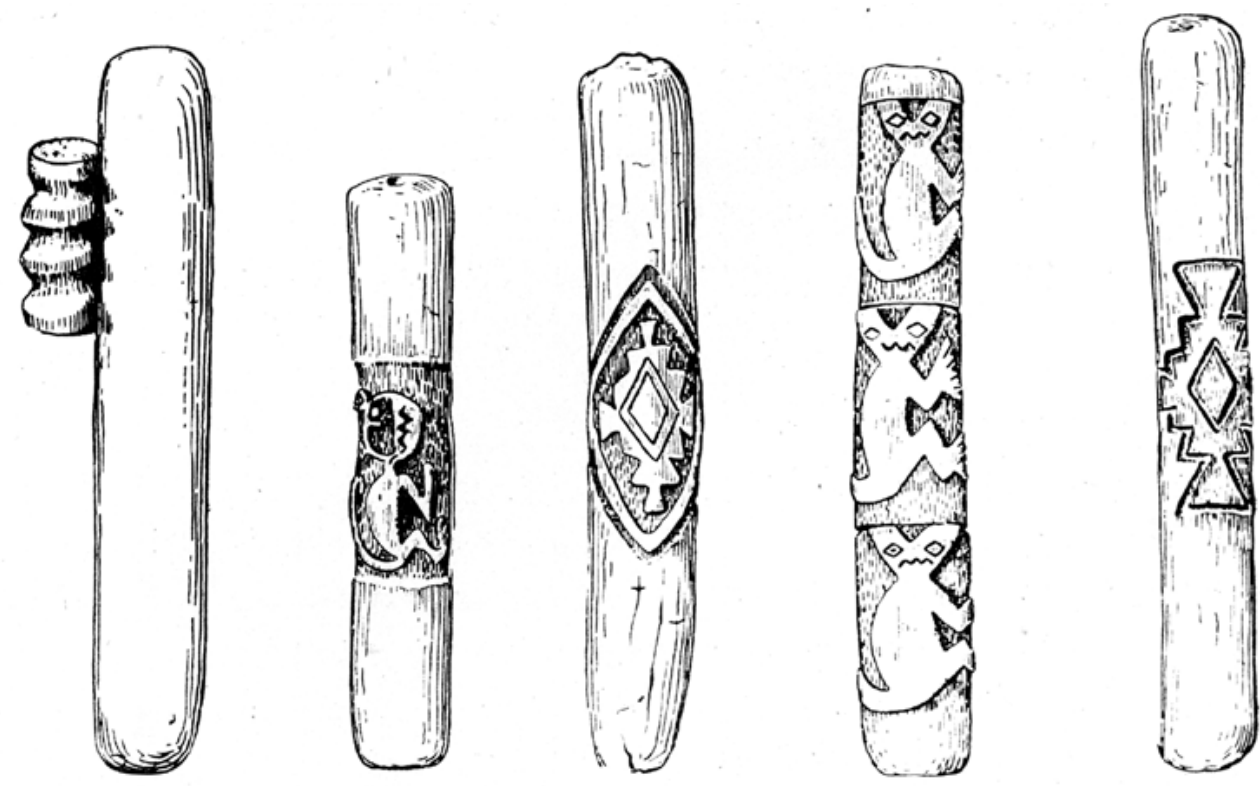

FIG. 17

Hachas de tres clases al menos ${ }^{57}$, cabezas de mazas en forma de estrellas ${ }^{58}$; cuchillos ó tumis $^{59}$, topos $^{60}$, cinceles, pinces y campanillas de lata doblada ${ }^{61}$, agujas y copas de madera grabadas ${ }^{62}$, vasitos de madera y barro, en forma de pájaros ${ }^{63}$, etc. Todas estas cosas son idénticas y prueba de entierros peruanos del tiempo incaico ó de hallazgos argentinos. Algunos de ellos pueden fácilmente ser reconocidos como incaicos, por ejemplo, un vaso representado por Outes, que enseña la influencia incaica sólo por una serpiente en relieve ${ }^{64}$, ó un vasito cilíndrico de madera representado por Ambrosetti, que reproduce la forma de los morteros incaicos en tamaño menor y sin sus asas ${ }^{65}$, ó los palitos de madera ${ }^{66}$, que serían únicos en su forma, si un número de nueva iguales no se hubiesen encontrado en un entierro incaico cerca de Inca (fig. 17).

No cabe preguntar si los Incas dominaron todo el país ó solamente las partes adyacentes del camino, hasta que podemos seguir por sus artefactos sus huellas hasta San Juan, punto que, parece, haber recibido su influencia.

57 Ambrosetti, Bronce, páginas 208, 212, 214, 215. Formas idénticas en colecciones del Cuzco, del Ecuador (Kultur und Industrie, I, pl. 16). El hacha, Bronce, página 235, figura 52 es típicamente incaico y se encuentra de manera idéntica en colecciones del Cuzco.

58 Bronce, página 234. Común en colecciones del Cuzco y en entierros del período incaico (representaciones en el Museo de Lima).

59 Bronce, página 205. Esta forma de cuchillo es típicamente incaica y pertenece á los Incas solos.

60 Bronce, página 217. Topos idénticos al de figura 31 a se han encontrado en entierros del período incaico en el valle de Lima, etc. (Museo Nacional, $\mathrm{n}^{\circ}$ 5185-86, etc).

61 Bronce, página 227, figura 43 a, b. Idénticos se encontraron en entierros del período incaico del valle de Lima, Icayete (Museo Nacional, $\mathrm{n}^{\circ}$ 5224-3423, etc.) Por eso el objeto: Kultur und Industrie, I, plancha 25, figura 13 es también incaico.

62 Ambrosetti, La Paya, página 55 y 467. Objetos sumamente comunes en entierros del período incaico de la costa peruana. Varios de éstos de Cuzco, Chincha, Lima, en el Museo de Lima, otros de Ica, etc., en San Francisco. Compárese también Uhle, Pachacámac, plancha 13, figura 17, y plancha 18, figura 14.

63 Compárese La Paya, página 370, n 2111. Iguales comunes en entierros del período incaico en la costa del Perú, valle de Lima, Pachacámac, etc.

64 Outes, Alfarerías del noroeste argentino, 1907, plancha VII, figura 7, compárese los morteros de piedra del Cuzco.

65 Ambrosetti, La Paya, página 54, figura 31 (colección Centeno en el Museo de Berlín).

66 Sepulcro de La Paya, página 130, A-C. 